\title{
First Report of Barley Yellow Dwarf Viruses (BYDVs) on Dicotyledonous Weed Hosts in Turkey
}

\author{
H. IlbaĞI ${ }^{1 *}$, A. ÇitiR ${ }^{1}$, A. Kara ${ }^{1}$, M. Uysal ${ }^{2}$ and F. Azzouz Olden ${ }^{3}$ \\ ${ }^{1}$ Department of Plant Protection, Faculty of Agriculture, Namık Kemal University, Tekirdağ, Turkey \\ ${ }^{2}$ Department of Plant Protection, Faculty of Agriculture, Selçuk University, Konya, Turkey \\ ${ }^{3}$ Food Science \& Sustainable Systems Community Research, College of Agriculture, \\ Kentucky State University, Kentucky, USA
}

(Received 22 July 2018; Accepted 28 February 2019;

Communicated by A. Mohan)

\begin{abstract}
Yellow dwarf viruses (YDVs) are economically destructive viral diseases of cereal crops, which cause the reduction of harvested yield and quality of grains. Up to now the identification of such viruses was limited to monocotyledonous Poaceae weed hosts, and was not investigated in dicotyledons. In this study, using DAS-ELISA and RT-PCR methods, 6 dicotyledonous weed species, collected from Trakya, Turkey, were examined for the presence of the YDVs pathogens BYDV-PAV, BYDV-MAV, BYDV-RMV, BYDV-SGV and CYDV-RPV. The screening tests revealed certain samples of Geranium dissectum L. and Juncus compressus Jacq. were infected with BYDV-PAV, while other samples of the same species were positive for BYDV-MAV. Additionally, RT-PCR tests of both weed species revealed cases of mixed infection by BYDV-PAV and BYDV-MAV. Transmission experiments using the aphid species Rhopalosiphum padi L. showed that BYDV-PAV was transmitted persistently from Geranium dissectum to barley cv. Barbaros seedlings. To our knowledge, this is the first report of Geranium dissectum and Juncus compressus as possible plant hosts of BYDV-PAV and BYDV-MAV in Turkey.
\end{abstract}

Keywords: BYDV, dicotyledon weed host, cereal

\section{Introduction}

Trakya is one of the most fertile cereal growing areas in Turkey. However, prevailing pests and diseases have reduced the grain yield and quality, which almost never reach the production potential (Ilbağı et al. 2013). Beside the very damaging fungal diseases of cereals, YDVs (also known as Barley yellow dwarf viruses, BYDVs) occur worldwide since they were first reported in California (Oswald and Houston 1951). With regards to Turkey, Bremer and Raatikainen related the first sporadic BYDVs infections in 1975 in the Western regions of the country, and later, 52 Poaceae host species were identified in the neighboring Greece (Panayotou 1982). In the subsequent years, the spread of BYDV-PAV and CYDV-RPV was observed in Spain (Moriones and Garciaarenal 1991). At present, the Yellow dwarf viruses (YDVs), of the Luteoviridae family, represent the

*Corresponding author; E-mail: hilbagi@nku.edu.tr 
most widespread group of cereal viruses worldwide. To prevent BYDV disease epidemics and to develop control strategies in field condition it is imperative to assess and identify the host range, the environmental conditions, the infecting viral strains and the transmitting aphid species (D'Arcy and Burnett 1995). With regard to the host range, in addition to cultivated cereals, D'Arcy (1995) compiled a list of 96 annual, 2 biannual and 111 perennial Poaceae weed hosts worldwide. In Trakya, YDVs diseases with typical symptoms such as yellowing, dwarfing, reddening and reduction of grain yield and quality were recorded in winter wheat (Triticum aestivum L.), barley (Hordeum vulgare L.), oat (Avena sativa L.), triticale (X Triticosecale Wittmack) and bird seed (Phalaris canariensis L.) (İlbağı 2003). BYDVs, CYDV-RPV and WDV were also reported in 15 other cereal producing provinces of Turkey (Pocsai et al. 2003; Ilbağı et al. 2003). Concerning YDVs virulence, Garrett et al. (2004) investigated the presence of YDVs in four dominant tallgrass species in the American Midwest, and identified BYDV-MAV, BYDV-RMV and BYDV-SGV as the infecting agents. Bisnieks et al. (2004) confirmed the differences between the virulent BYDV-PAV and the weakly virulent BYDV-MAV species by assessing the molecular diversity of the $\mathrm{CP}$ encoding regions. Compiled studies of incidence and the rate of infections revealed that BYDV-PAV is the most virulent cereal virus species in Turkey (Ilbağ1 et al. 2005). Pakdel et al. (2010) studied the Luteovirus species hosted by wheat, barley and wild grass in Southern Iran. The outcomes revealed genetically distinct BYDV-PAV isolates and a new species, BYDV-PAS was, thus, suggested. Weed grasses have been identified as the sources of YDVs infection in many countries as reported in Latvia (Bisnieks et al. 2004), The Chech Republic and Sweden (Pokorny 2006), Australia (Hawkens and Jones 2005) and in Bulgaria (Bakardjeiva et al. 2006). In the Trakya Region, common reed (Phragmites communis Trin.) was identified as the oversummering and overwintering host of BYDV-PAV and CYDVRPV, (Ilbağ 2006 ), and the bird seed Phalaris canariensis L. was also identified as another host of YDVs (Ilbağ1 et al. 2008). Güncan (2010) suggested effective weed control in and around cereal fields to eliminate sources of YDVs to prevent these primary infections, as well as competition for nutrients and moisture with cultivated cereals. Aphid species transmit YDVs in a persistent manner. Kınacı and Yakar (1984) identified 2 aphid vectors. Çalı and Yurdakul (1996) reported 4 others aphid vectors in the Central Anatolia Region of Turkey. Halbert and Voegtlin (1995) biologically characterized 25 aphid vectors of which 10 are commonly found in cereal fields. Seven of these aphids were found in wheat fields in the Tekirdağ Province of Turkey (Özder and Toros 1999). Power and Gray (1995) cited that, beside aphid vector species, vector density and population dynamics have a significant impact on the rate of BYDV diseases. Viral spread is especially, influenced by the movement of the vector when selecting infected plants for their yellow color, and then moving to healthy green plants on the basis of gustatory cues. Because of the direct interactions between viruses and aphid vectors and their host plants including weed hosts, it is crucial to investigate all the components of this system. One such component, is the ecological niche. Power et al. (2011) investigated the ecology of BYDVs and CYDVs in grassland of the Western USA, and established that YDVs were localized in the latitudinal gradient $\left(33.8-48.8^{\circ} \mathrm{N}\right)$ from Southern California to 
Southern Canada. They proved that annual grass species introduced from Europe were necessary for prevalence and coinfections of YDVs. The same study showed that the epidemics of YDV diseases were shaped by interactions of host plants, vectors, vertebrate herbivores and the abiotic conditions like plant nutrients. Similarly, Parry et al. (2012) investigated the geographical distribution of YDVs and aphid vectors in the Australian grasslands and wheat fields. They determined that BYDV-PAV and its vector Rhopalosiphum padi L. were widespread in wheat fields and grasslands across the country, except Queenland where BYDV-RMV and its vector $R$. maidis L. were prevalent. Lamptey et al. (2012) investigated, under greenhouse conditions, the susceptibility to YDVs of 3 major biomass grasses in the UK (Phalaris arundinacea L. Miscanthus sinesis Anderss. and Echinochloa crus-galli (L.) Beauv.). The results showed E.crus-galli was susceptible to BYDV-PAV, BYDV-MAV and CYDV-RPV, P. arundinacea to BYDV-MAV and CYDV-RPV, and M. sinesis only susceptible to BYDV-MAV. These infections caused $20-40 \%$ reduction of dry matter yield in the UK grassland. Finally, in Turkey, BYDV-PAV was identified in a number of Poaceae weed hosts in Trakya Region (Ilbağ1 et al. 2011). At present, 8 species of YDVs have been identified, and classified into Luteoviridae family (Domier 2012). The BYDV strains were separated into BYDV and CYDV species, and classified into 2 respective genera, Luteovirus and Polerovirus. Krueger et al. (2013) suggested that BYDV-RMV be renamed "Maize yellow dwarf virus" (MYDV) and classified into the Polerovirus genus with the other CYDVs such as Wheat yellow dwarf virus (WYDV). Traditionally, worldwide including in Turkey (Ilbağ1 et al. 2013), YDVs host range studies focused on monocotyledonous Poaceae species. More recently, Ju et al. (2017) investigated the systemic infection of BYDV and the molecular characterization of these viruses in a dicotyledonous species, Nicotiana benthamiana. BYDV synthesis and cell to cell movement through plasmodesmata was thus confirmed in a dicotyledonous indicator plant. In this study, field surveys were conducted in the Turkish Trakya Region during the years of 2011 and 2012 to screen for the presence of Barley yellow dwarf viruses (BYDV-PAV, BYDV-MAV, BYDV-RMV, BYDV-SGV) and Cereal yellow dwarf virus-RPV (CYDV-RPV) in weed hosts other than the species of Poaceae family. For this purpose, a total of 40 weed leaf samples belonging to 6 species were screened for BYDVs and CYDV-RPV using polyclonal antibodies with DAS-ELISA and RT-PCR methods. Concerning the detection of the BYDV-SGV and BYDV-RMV isolates, only RT-PCR was performed. The amplified products were sequenced, and phylogenetic trees were constructed and compared with published sequences of other BYDVs available in the GenBank/EMBL databases.

\section{Material and Methods}

\section{Survey studies and sampling}

Survey studies were implemented in 12 counties of Trakya that were visited in June 2011 and 2012 (Fig. 1). A total of 40 symptomatic weed leaf samples belonging to 6 dicotyledonous weed species of 5 families were collected from road side verges, hedge grows of 


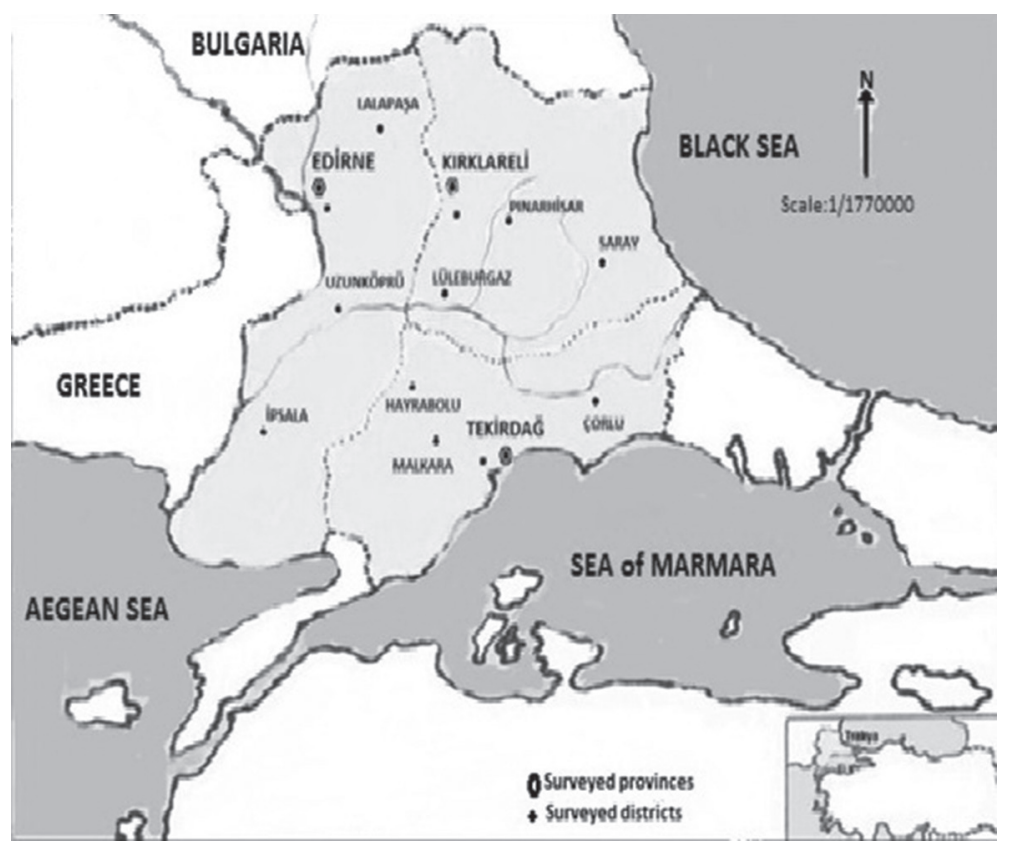

Figure 1. Twelve districts in the Trakya Region of Turkey where YDVs investigated

cereal fields, rice field dikes and banks of creeks. Intact weed plants representing each species were also collected to identify aphid transmissions and herbariums. Intact weeds for each species were transplanted into $5 \mathrm{~L}$ pots and kept alive in greenhouse conditions.

\section{Indicator plant production and aphid transmission}

Barley (cv. Barbaros) was selected as indicator plants of BYDVs. Six seeds were sown into $500 \mathrm{ml}$ pots filled with sterilized mixture of soil, sand and compost (1:1:1). Aphid species Rhopalosiphum padi L. Rhopalosiphum maidis L. Sitobion avenae (Fab.), Metopolophium dirhodum (Walker) and Schizaphis graminum (Rondani) were identified and cultured on healthy wheat (cv. Attila 12) plants. Aphid transmissions were performed as suggested by Du et al. (2007). Using a camel hair brush, apteral individuals were collected in petri dishes and placed on transplanted weeds and left to feed for $72 \mathrm{~h}$ for acquisition of YDVs viral particles. For plant inoculation, at the 2-leaf stage, 1 pot was allocated for each aphid species and 5 viruliferous aphids were placed per plant. This procedure was repeated for all transplanted weeds saving 1 pot of healthy barley plants as control. Five days of post-inoculation, the aphids were killed by spraying insecticide and the plants were maintained at $20^{\circ} \mathrm{C}$ in an insect-proof greenhouse till the plants exhibited viral symptoms. 


\section{Serological test}

A total of 40 weeds leaf samples were tested with polyclonal antibodies (manufactured by AGDIA Inc. Elkhart IN, USA) for the presence of BYDV-PAV, BYDV-MAV and CYDVRPV viruses. Double Antibody Sandwich Enzyme-Linked Immunosorbent Assays (DAS-ELISA) was performed as described by Clark and Adams (1977). Optical densities at $405 \mathrm{~nm}$ (OD405) were measured with an ELISA reader (Thermo Fischer Scientific Instruments Co. Ltd. Waltham, MA, USA), and a positive reaction was recorded when the OD405 of a sample was twice that given by the sample of the healthy control plant.

\section{Nucleic acid isolation from YDVs infected samples}

The obtained 40 weed and aphid transmitted barley leaf samples were subjected to the isolation of the viral nucleic acids by employing the total nucleic acid extraction method described by Falke et al. (2000).

\section{cDNA synthesis}

First strand cDNA was synthesized from total isolated RNA by using RevertAid ${ }^{\mathrm{TM}}$ First Strand cDNA Kit (Fermentas; Vilnius, Lithuania). In each reaction, $0.5 \mu \mathrm{g}$ RNA sample and 20 pmol of Reverse complementary primer pair of BYDVs and CYDV-RPV were used and processed according to the manufacturer's instructions.

\section{RT-PCR amplification}

RT-PCR was carried out with different sets of specific and degenerate primer pairs for the amplification of coat protein region of the Yellow dwarf viruses (YDVs) as shown in Table 1. For the amplification of BYDV-PAV cDNA fragments, degenerate primers were used (Robertson et al. 1991), while specific primers were used for BYDV-MAV, BYDVRMV, BYDV-SGV and CYDV-RPV (Deb and Anderson 2007). The PCR reaction mixture contained $2 \mu \mathrm{cDNA}, 10 \mathrm{mM}$ dNTPs, $10 \mu \mathrm{M}$ each of forward and reverse primers, 10x PCR buffer, $\mathrm{MgCl}_{2}(25 \mathrm{mM}), 2.5 \mathrm{U}$ of Taq DNA polymerase (Fermentas; Vilnius, Lithuania) and RNase free water in a $25 \mu \mathrm{l}$ reaction volume. PCR conditions were optimized for each virus against a range of concentrations and annealing and extension temperatures. The PCR cycling conditions for BYDV-PAV consisted of an initial denaturation at $94{ }^{\circ} \mathrm{C}$ for $2 \mathrm{~min}$, followed by 40 cycles at $94{ }^{\circ} \mathrm{C}$ for $1 \mathrm{~min}, 43{ }^{\circ} \mathrm{C}$ for $1 \mathrm{~min}, 72{ }^{\circ} \mathrm{C}$ for $1 \mathrm{~min}$. and the final extension step at $72^{\circ} \mathrm{C}$ for $10 \mathrm{~min}$. The thermal cycling conditions for BYDV-MAV, BYDV-RMV and BYDV-SGV consisted of 40 cycles at $95^{\circ} \mathrm{C}$ for 30 sec, $55^{\circ} \mathrm{C}$ for $1 \mathrm{~min}, 72^{\circ} \mathrm{C}$ for $1 \mathrm{~min}$ and the final extension step at $72{ }^{\circ} \mathrm{C}$ for $10 \mathrm{~min}$. Cycling conditions of CYDV-RPV comprised an initial denaturation at $94{ }^{\circ} \mathrm{C}$ for 2 min, followed by 40 cycles at $94{ }^{\circ} \mathrm{C}$ for $30 \mathrm{sec}, 60{ }^{\circ} \mathrm{C}$ for $45 \mathrm{sec}, 72{ }^{\circ} \mathrm{C}$ for $1 \mathrm{~min}$ and the final extension step at $72{ }^{\circ} \mathrm{C}$ for $10 \mathrm{~min}$ in thermal cycler. The obtained PCR products were analyzed by electrophoresis in 1.5\% agarose gel, stained with EtBr and viewed under UV 
Table 1. Specific and degenerate primer pairs of YDVs using in RT-PCR detection method

\begin{tabular}{|c|c|c|c|c|}
\hline Virus & Primer & Sequence & NCBI accession & $\begin{array}{l}\text { Amplicon } \\
\text { size (bp) }\end{array}$ \\
\hline BYDV-PAV & $\begin{array}{l}\text { Lu1 } \\
\text { Lu4 }\end{array}$ & $\begin{array}{l}\text { CCAGTGGTTRTGGTC } \\
\text { GTCTACCTATTTGG }\end{array}$ & D11032.1 & 530 \\
\hline BYDV-MAV & $\begin{array}{l}\text { L1 } \\
\text { R1 }\end{array}$ & $\begin{array}{l}\text { CAACGCTTAACGCAGATGAA } \\
\text { AGGACTCTGCAGCACCATCT }\end{array}$ & D11028.1 & 175 \\
\hline BYDV-RMV & $\begin{array}{c}\mathrm{L} 1 \\
\mathrm{R}\end{array}$ & $\begin{array}{l}\text { GACGAGGACGACGACCAAGTGGA } \\
\text { GCCATACTCCACCTCCGATT }\end{array}$ & L12757.1 & 365 \\
\hline BYDV-SGV & $\begin{array}{l}\mathrm{L} 2 \\
\mathrm{R} 2\end{array}$ & $\begin{array}{l}\text { ACCAGATCTTAGCCGGGTTT } \\
\text { CTGGACGTCGACCATTTCT }\end{array}$ & AY541039.1 & 237 \\
\hline CYDV-RPV & $\begin{array}{l}\mathrm{L} \\
\mathrm{R}\end{array}$ & $\begin{array}{l}\text { ATGTTGTACCGCTTGATCCAC } \\
\text { GCGAACCATTGCCATTG }\end{array}$ & AF235168.2 & 400 \\
\hline
\end{tabular}

illumination in a gel documentation system (Vilber Lourmet; Marne La Vallee Cedex 1, France).

\section{Sequencing of RT-PCR products}

For sequence analysis, the PCR products were purified from agarose gels using QIAquick gel extraction kit (MBI Fermentas; St. Leon-Rot, Germany) in accordance with the manufacturer's protocol and sequenced by Refgen (Biotechnology Company, Ankara, Turkey). The resulting nucleotides and deduced amino acid sequences were aligned with the Bioedit Program. The alignments were used as input data to construct phylogenetic trees with the neighbor joining distance method implemented in Mega 5.0 program (Tamura et al. 2011). Pairwise sequence comparisons were calculated with the BioEdit Program. Bootstrap analysis with 1000 replicates was performed to assess the robustness of the branches.

\section{Results}

The present survey study included 12 districts of Trakya and resulted in the collection of 40 symptomatic dicotyledonous weed samples from 6 species belonging to 5 families (Table 2).

Such samples exhibited systemic symptoms, like mosaic, reddening, irregular necrotic patches, yellowing, necrotic leaf spots and distortions similar to symptoms of YDVs on Poaceae weeds. Among these Dicotyledonae weed species, Geranium dissectum which is a member of Geraniaceae family as exhibited in Figure 2, revealed green and red color mixture of mosaic and the bright red leaves. Another Dicotyledonous weed was an aquatic weed, Juncus compressus, being a member of Juncaceae family, occurred solely on rice field borders and dikes also exhibited some degree of chlorosis and yellowing as shown in Figure 2. 

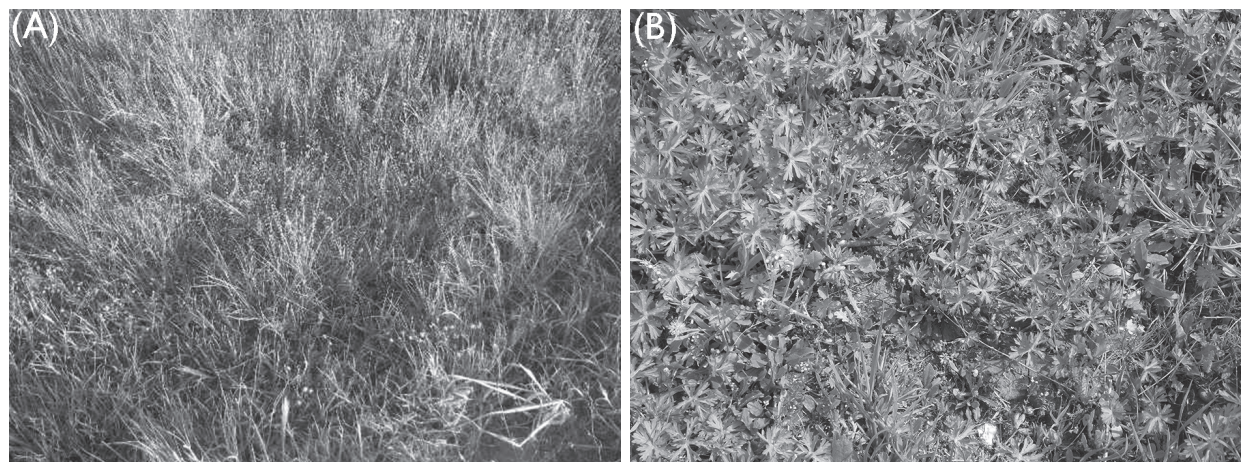

Figure 2. Juncus compressus (A) and Geranium dissectum (B) weed hosts of YDVs exhibiting systemic symptoms like mosaic, reddening, necrotic leaf spots

The results of the aphid transmission tests showed that apterous Rhopalosiphum padi L. transmitted BYDV-PAV from $G$. dissectum to barley (cv. Barbaros) seedlings. On the contrary, transmission attempts of BYDV-PAV from $J$. compressus to Barbaros barley seedlings failed. All other tests using other aphid species to transmit BYDV-MAV, BYDV-RMV, BYDV-SGV and CYDV-RPV from suspected Dicotyledonae weed sources to barley seedling were negative. The results of DAS-ELISA and RT-PCR tests (Table 2) revealed that 4 out of $17(23.53 \%)$ G. dissectum samples were infected with BYDV-PAV, and 2 out of $17(11.76 \%)$ samples were BYDV-MAV positive. Also, 2 out of 17 samples $(11.76 \%)$ were infected with the mixture of BYDV-PAV+BYDV-MAV. In the case of J. compressus, 2 out of 3 samples were, respectively, BYDV-PAV and BYDV-MAV positive, and the third sample was infected with the mixture of both viruses. Virus detection tests, were negative for the remaining weed species and viruses screened in this study. The genomic region of the coding coat protein (CP) of BYDV-PAV was amplified via RT-PCR in order to complete the molecular characterization of the strain. The DNA fragments $(530 \mathrm{bp})$ were amplified from 2 isolates of BYDV-PAV from G. dissectum and $J$. compressus samples collected in Tekirdağ, Saray district and Edirne, Ipsala district. The DNA fragments (175 bp) of BYDV-MAV were amplified from 3 isolates obtained from 2 samples of $G$. dissectum collected in Tekirdağ (Malkara district) and 1 sample of

Table 2. Screening of BYDV in the symptomatic Dicotyledonae weed samples collected in 2011 and 2012 in the Trakya Region of Turkey. Samples were tested using DAS-ELISA and RT-PCR

\begin{tabular}{|l|c|c|c|c|c|}
\hline \multicolumn{1}{|c|}{ Names of species } & $\begin{array}{c}\text { Number of } \\
\text { samples }\end{array}$ & BYDV-PAV & BYDV-MAV & PAV+MAV & $\begin{array}{c}\text { Virus infected } \\
\text { samples }\end{array}$ \\
\hline Carex divisa Huds. & 1 & - & - & - & - \\
Galium aparine L. & 13 & - & - & - & - \\
Geranium dissectum L. & 17 & 4 & 2 & 1 & 3 \\
Juncus compressus Jacq. & 3 & 1 & 1 & - & - \\
Lactuca seriola L. & 2 & - & - & - & - \\
Sonchus asper (L.) Hill & 4 & - & 3 & 3 & 11 \\
\hline Total & 40 & 5 & & & \\
\hline
\end{tabular}




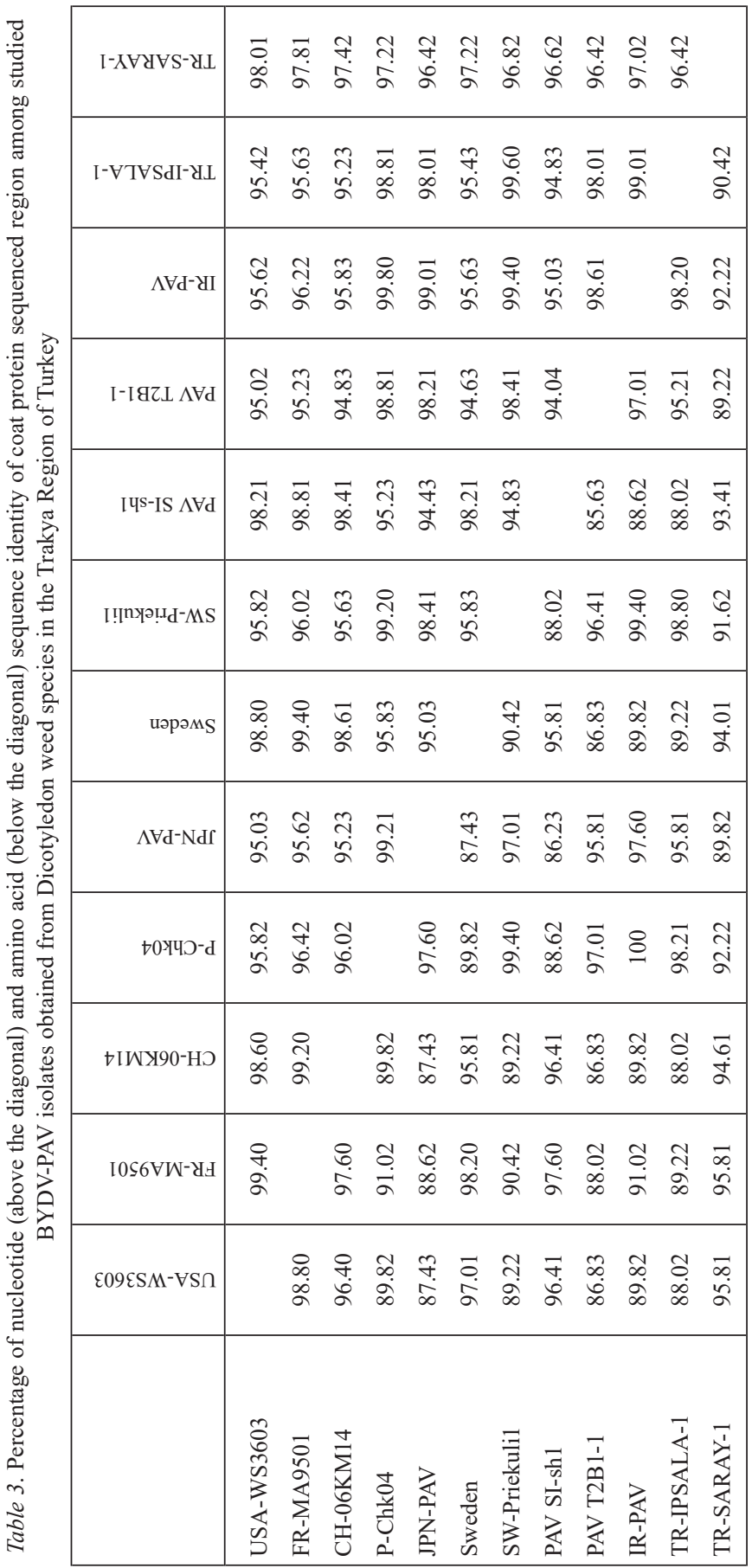

Cereal Research Communications 47, 2019 
J. compressus from Edirne (Ipsala district). Upon amplification, multiple sequence alignments and pairwise sequence comparisons were performed using Bioedit Software Program (Tables 3,4). Thus, the sequence analysis of the Turkish BYDV-PAV and

Table 4. Percentage of nucleotide (above the diagonal) and amino acid (below the diagonal) sequence identity of coat protein sequenced region among studied BYDV-MAV isolates obtained from Dicotyledon weed species in the Trakya Region of Turkey

\begin{tabular}{|l|c|c|c|c|}
\hline & MAV-JOR & MAV-PS1 & MAV-Malkara1 & MAV-Ipsala1 \\
\hline MAV-JOR & & 91.33 & 98.27 & 94.22 \\
MAV-PS1 & 78.95 & & 93.06 & 95.95 \\
MAV-Malkara1 & 94.74 & 84.21 & & 95.38 \\
MAV-Ipsala1 & 84.21 & 91.23 & 87.72 & \\
\hline
\end{tabular}

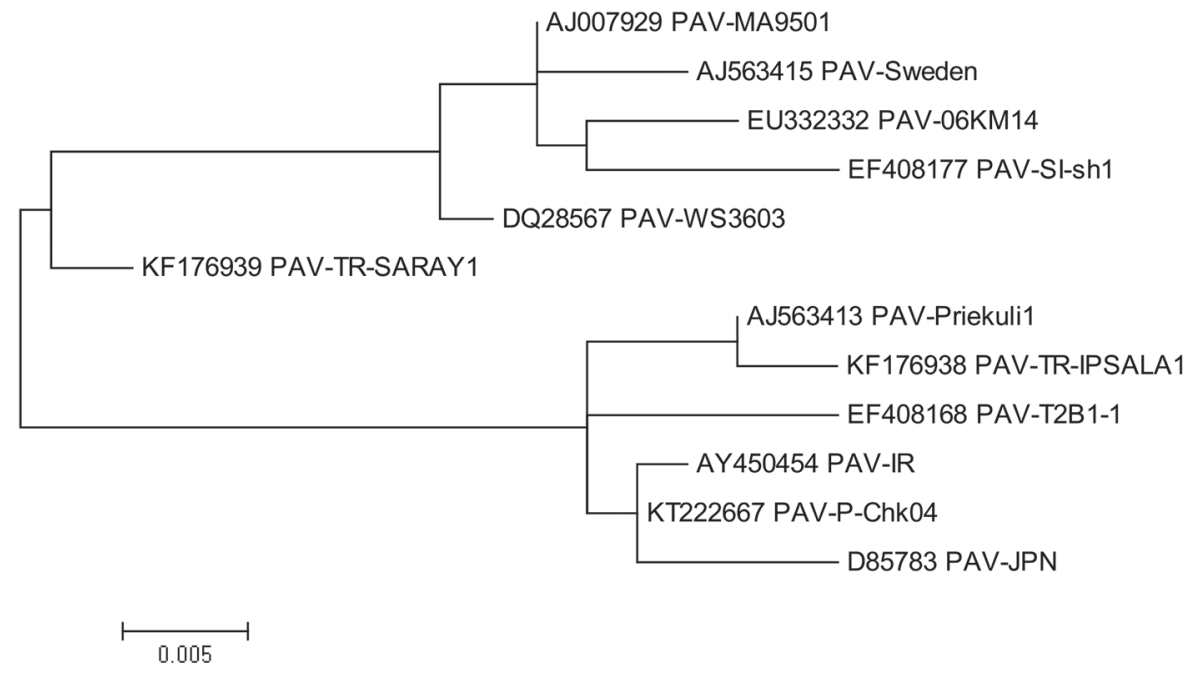

Figure 3. Constructed phylogenetic tree of BYDV-PAV based on partial nucleotide sequencing results of PCR products

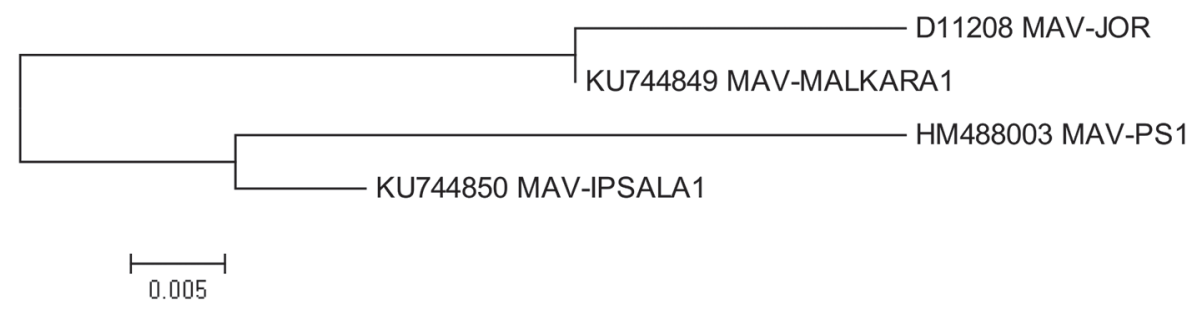

Figure 4. Constructed phylogenetic tree of BYDV-MAV based on partial nucleotide sequencing results of PCR products 
BYDV-MAV isolates were compared with 12 accessions available in GenBank/EMBL database. These public accessions included (PAV-NY, PAV-DB2b, IR-PAV, JPN-PAV, PAV T2B1-1, MA9502, 06KM14, PSW2, Sweden, Priekuli1, MAV-JOR, MAV-PS1). The constructed phylogenetic tree of these sequences, obtained using Mega5, revealed two clustered groups, placing the two BYDV-PAV isolates of this study within the second group with a 94.83-99.60\% similar nucleotide identity. The similarity of the amino acids of our BYDV-PAV isolates was $88.02-98.80 \%$ with BYDV-PAV isolates from the USA, China, New Zeland and Sweden (Fig. 3). Both Turkish BYDV-MAV that we isolated were compared with the other MAV strains. Our MAV-MALKARA1 isolate exhibited 93.06\% nucleotid identity with MAV-PS1 strain from the USA. The other MAVMALKARA1 isolate of this study showed more similar nucleotid identity $(98.27 \%)$ with MAV-JOR. However, the similarity of the amino acids of our BYDV-MAV isolates were 84.21-94.74\% with BYDV-MAV isolates from the USA and Jordan (Fig. 4).

\section{Discussion}

Up to now, the diseases caused by BYDVs were limited to Monocotyledonous Poaceae weeds, which were identified as the natural hosts of such pathogens (Panayotou 1982; Moriones and Garciaarenal 1991; D’Arcy 1995; Bisnieks et al. 2004; Pokorny 2006; Bakardjeiva et al. 2006). The most exhaustive list of Poaceae weed species that are hosts of BYDVs includes 209 species that are all of the Monocotyledonous group (D'Arcy 1995). In the present study, we discovered two Dicotyledonous weeds that are host species of two viral types, BYDV-PAV and BYDV-MAV, in fact, G. dissectum and J. compressus were identified as over summering hosts of such viruses. These results are in accord with the various host range studies of YDVs in different parts of the world, which established that pastures and grasslands are hubs of infectious agents (Garrett et al. 2004; Hawkens and Jones 2005; Bisnieks et al. 2006; Ilbağ1 et al. 2011; Power et al. 2011; Parry et al. 2012; Lamptey et al. 2012; Ilbağ1 et al. 2013). The vector $R$. padi is a permanently anholocyclic aphid species reproducing abundantly in autumn, and is considered to be the most important vector of BYDV-PAV and CYDV-RPV (Halbert and Voegtlin 1995). Hence, such an efficient vector may transmit BYDV-PAV from Monocotyledonae cereal species to Dicotyledonae plant species. Because of the worldwide climatic changes, winter season has been getting warmer than ever recorded before. In that regard, detailed investigations on BYDVs host range may provide new susceptible. Thus, the life cycle of aphids might be altered from holocyclic reproduction type to anholocyclic type of reproduction. Since vector aphid behaviors are changing so drastically, the host range of BYDVs also might be changing host plants as identified in the present study. Thus, with these results, it is possible to confirm that 2 Dicotyledonae weeds in the Edirne and Tekirdağ Provinces of Turkey, plant species, namely, G. dissectum and J. compressus might be added as the first recorded indication that the host range of BYDV-PAV as well as BYDV-MAV expands to other plant species. As a matter of fact, Ju et al. (2017) recently investigated systemic infection of BYDV species, synthesis of viruses and cell to cell movement through plasmodesmata in a Dicotyledonae indicator plant. To our knowl- 
edge, this is the first report of BYDV-PAV and BYDV-MAV in Geranium dissectum and Juncus compressus weeds in Turkey.

\section{Acknowledgments}

We would like to thank to Turkish Scientific and Technological Research Council (TÜBİTAK) for the valuable support to Project 1090522, from part of its results this work was obtained.

\section{References}

Bakardjieva, N., Krasteva, C., Habekuss, A., Rabenstein, F. 2006. Detection of cereal viruses and study of aphid population in Bulgaria. Institute of Plant Protection 43:499-501.

Bremer, K., Raatikainen, M. 1975. Cereal diseases transmitted or caused by aphids and leafhoppers in Turkey. Ann. Acad. Sai. Fenn. A., IV. Biologica 203:1-14.

Bisnieks, M., Kvarnheden, A., Sigvald, R., Valkonen, J.P.T. 2004. Molecular diversity of the coat proteinencoding region of Barley yellow dwarf virus-PAV and Barley yellow dwarf virus-MAV from Latvia and Sweden. Arch. Virol. 149:843-853.

Bisnieks, M., Kvarnheden, A., Turka, I., Sigvald, R. 2006. Occurrence of Barley yellow dwarf virus and Cereal yellow dwarf virus in pasture grasses and spring cereals in Latvia. Acta Agr. Scand. B-S.P. 56:171-178.

Clark, M.F., Adams, A.N. 1977. Characteristics of the microplate method of enzyme-linked immunosorbent assay for the detection of plant viruses. J. Gen. Virol. 34:475-483.

Çal1, S., Yurdakul, S. 1996. Investigation on virus diseases of wheat in Central Anatolia.5 th. International Wheat Conference. June10-14. Ankara, Turkey. p. 120.

D’Arcy, C.J. 1995. Symptomatology and host range of Barley yellow dwarf. In: D'Arcy, C.J., Burnett, P.A. Barley yellow dwarf 40 years of progress. APS Press, St. Paul, MN., USA. p. 9-28.

D’Arcy, C.J., Burnett, P.A. 1995. Barley yellow dwarf: A brief introduction. In: D’Arcy, C.J., Burnett, P.A. Barley yellow dwarf 40 years of progress. APS Press, St. Paul, MN., USA. p. 1-5.

Deb, M., Anderson, J.M. 2007. Development of a multiplexed PCR detection method for Barley and Cereal yellow dwarf viruses, Wheat spindle streak virus, Wheat streak mosaic virus and Soil-borne wheat mosaic virus. J. Virol. Methods 148:17-24.

Domier, L.L. 2012. "Family Luteoviridae". Pages 1045-1053 in Virus taxonomy, 9th Ed. Andrew, M.Q.K. Elliot, L., Mickhael, J.A., Carstens, E.B. (eds). Elsevier Academic Press, San Diego, CA, USA.

Du, Z.Q., Li, L., Wang, X.F., Zhou, G. 2007. Evaluation of aphid transmission abilities and vector transmission phenotypes of Barley yellow dwarf viruses in China. J. Plant Pathol. 89(2):251-259.

Falke, K.C., Friedt, W., Ordon, F. 2000. Nachweis der expression von Bci-4 und Lox:2 Hv1 in Gerste (Hordeum vulgare L.) nach DCINA Applikation, (Diplomarbeit), Justus Liebig Universitaet Planzenbau und Pflanzenzüchtung.

Garrett, K.A., Dendy, S.P., Power, A.G., Blaisdell, G.K., Alexander, H.M., McCarron, J.K. 2004. Barley yellow dwarf diseases in natural populations of dominant tallgrass prairie species in Kansas. Plant Dis. 88(5):574.

Güncan, A. 2010. Weeds and weed control. Selçuk University, Teknik Bilimler MYO, T.B. Yayım Atelyesi. Konya, Turkey. p. 278.

Halbert, S., Voegtlin, D. 1995. Biology and taxonomy of vectors of Barley yellow dwarf viruses In: D’Arcy, C.J., Burnett, P.A. Barley yellow dwarf 40 years of progress. APS Press, St. Paul, MN. USA. APS Press, St. Paul, MN., USA. pp. 217-258.

Hawkens, J.R., Jones, R.A.C. 2005. Incidence and distribution of Barley yellow dwarf virus and Cereal yellow dwarf virus in over-summering grasses in a mediterranean-type environment. Aust. J. Agr. Res. 56(3):257270.

Ilbağı, H. 2003. Identification of viruses as causal agents of yield loosing infections on some cereal crops in Trakya Region of Turkey. Ph.D. Thesis. Ege University, Graduate School of Natural and Applied Sciences. pp. 136.

Cereal Research Communications 47, 2019 
Ilbağı, H., Pocsai, E., Çıtır, A., Muranyi, I., Vida, G., Korkut, K.Z. 2003. Results of two years study on Incidence of Barley yellow dwarf viruses, Cereal yellow dwarf virus-RPV and Wheat dwarf virus in Turkey. $3^{\text {rd }}$ International Plant Protection Symposium. Debrecen, Hungary. October 15-16. p. 53-63.

Ilbağı, H., Çıtır, A., Yorganc1, U. 2005. Occurrence of virus infections on cereal crops and their identifications in the Trakya region of Turkey. J. Plant Dis. Protect. 112(4):313-320.

Ilbağ1, H. 2006. Common reed (Phragmites communis) is a natural host of important cereal viruses in the Trakya Region of Turkey. Phytoparasitica 34(5):441-448.

Ilbağı, H., Rabenstein, F., Habekuss, A., Ordon, F., Çıtır, A., Cebeci, O., Budak, H. 2008. Molecular, serological and transmission electron microscopic analysis of the Barley yellow dwarf virus-PAV and Cereal yellow dwarf virus-RPV in canary seed (Phalaris canariensis L.). Cereal Res. Commun. 36(2):225-234.

İlbağı, H., Çıtır, A., Uysal, M., Kara, A. 2011. Incidence and molecular characterization of Barley yellow dwarf virus-PAV on Poaceae weeds in the Trakya region of Turkey. Plant Genomics European Meetings. İstanbulTurkey. May 4-7. p. 63.

İlbağı, H., Çıtır, A., Kara, A., Uysal, M. 2013. Poaceae weed host range of luteoviridae viruses in the Trakya Region of Turkey. 16 ${ }^{\text {th }}$ Symposium European Weed Research Society. Samsun-Turkey. June 24-27. p. 98.

Ju, J., Kim, K., Lee, K.L., Lee, W.H., Ju, H.J. 2017. Barley yellow dwarf virus movement protein modulating programmed cell death in Nicotiana benthamiana. Plant Pathol. J. 33(1):53-65.

Kınac1, E., Yakar, K. 1984. Situation reports. Turkey. p. 196, In: Barley yellow dwarf, a Proceedings of the Workshop. P.A. Burnett (ed.) CIMMYT, Mexico D.F., Mexico. pp. 209.

Krueger, E.N., Beckett, R.J., Gray, S.W., Miller, W.A. 2013. The complete nucleotide sequence of the genome of Barley yellow dwarf virus-RMV reveals it to be a new polerovirus distantly related to other yellow dwarf viruses. Frontiers Microbiol. 4:1-11.

Lamptey, J.N.L., Plumb, R.T., Shaw, M.W. 2012. Interactions between the grasses Phalaris arundinacea, Miscanthus sinesis and Echinochloa crus-galli and barley and cereal yellow dwarf viruses. J. Phytopathol. 160: $13-18$.

Moriones, E., Gareiaarenal, F. 1991. Occurrence of Barley yellow dwarf viruses in small-grain cereals and alternative hosts in Spain. Plant Dis. 75(9):930-934.

Oswald, J.W., Houston, B.R. 1951. A new virus disease of cereals, transmissible by aphids. Plant Dis. Rep. 11:471-475.

Özder, N., Toros, S. 1999. Tekirdağ İli’nde buğdaylarda zarar yapan yaprak biti türlerinin Saptanması üzerinde araştırmalar. Türkiye Entomol. Derg. 23:101-110.

Pakdel, A., Afsharifar, A., Niazi, A., Almasi R., Izadpanah, K. 2010. Distribution of cereal luteoviruses and molecular diversity of BYDV-PAV isolates in Central and Southern Iran: Proposal of a new species in the genus Luteovirus. J. Phytopathol. 158:357-364.

Panayotou, P.C.1982. Some aspects on Barley yellow dwarf virus host range. Z. Pflanzenk. Pflanzen. 89:595603.

Parry, H.R., Macfadyen, S., Kriticos, D.J. 2012. The geographical distribution of yellow dwarf viruses and their aphid vectors in Australian grasslands and wheat. Aust. Plant Pathol. 41(4):375-387.

Pocsai, E., Ilbağı, H., Çıtır, A., Muranyi, I., Vida, G., Korkut, K.Z. 2003. Incedence of Barley yellow dwarf viruses, Cereal yellow dwarf virus and Wheat dwarf virus in cereal growing areas of Turkey. Agriculture 49:583-591.

Pokorny, R. 2006. Occurrence of viruses of the family Luteoviridae on maize and some annual weed Grasses in the Czech Republic. Cereal Res. Commun. 34(2-3):1087-1092.

Power, A.G., Gray, S.M. 1995. Aphid transmission of Barley yellow dwarf viruses: Interactions between viruses, vectors and host plants. In: D’Arcy, C.J., Burnett, P.A. Barley yellow dwarf 40 years of progress. APS Press, St. Paul, MN., USA. pp. 259-292.

Power, A.G., Borer, E.T., Hosseini, P., Mitchell, C.E., Seabloom, E.W. 2011. The community ecology of Barley/Cereal yellow dwarf viruses in Western U.S. grasslands. Virus Res. 159:95-100.

Robertson, N.L., French, R., Gray, S.M. 1991. Use of group-specific primers and the polymerase chain reaction for the detection and identification of Luteoviruses. J. Gen. Virol. 72:1473-1477.

Tamura, K., Peterson, D., Peterson, N., Stecher, G., Nei, M., Kumar, S. 2011. MEGA5: molecular evolutionary genetics analysis using maximum likelihood, evolutionary distance, and maximum parsimony methods. Mol. Biol. Evol. 28:2731-2739. 